\title{
The Influence of Unstable Shoes on Kinematics and Kinetics of the Lower limb Joints during Sit-to-stand task
}

\author{
Yun-Jin Kim¹, Ji-Won Park² \\ 'Department of Physical Therapy, General Graduate School, Catholic University of Daegu; '2Department of Physical Therapy, College of Medical \\ Science, Catholic University of Daegu, Daegu, Korea
}

Purpose: The purpose of this study was to investigate examine how the kinematics and kinetics of lower limb joints were changed depending on the unstable shoes (US) during sit-to-stand task (SitTS).

Methods: Nineteen healthy females were participated in this study. The subjects performed sit-to-stand task with US and barefoot. The experiment was repeated three times for each tasks with conditions. The kinematics and kinetics of lower limb joint were measured and analyzed using a 3-D motion analysis system. A paired t-test was utilised performed for to identificationy of changes in mean of angle, force, and moment between both the two conditions.

Results: The results of this study showed kinematic differences in lower limb joints during SitTS based on the US. The hip, knee, and ankle angle showed statistically significant differences during SitTS. At the initial of SitTS, Tthe force and moment of the hip flexor, hip extensor, knee flexor, knee extensor, ankle flexor, and ankle extensor showed statistically significant differences. At the terminal of SitTS, Tthe force and moment of the hip flexor, hip extensor, knee flexor, knee extensor, ankle flexor, and ankle extensor showed statistically significant differences. At the maximum of SitTS, Tthe moment of the hip extensor showed statistically significant differences. The force and moment of the ankle flexor, extensor moment showed statistically significant differences.

Conclusion: Therefore, Wwearing US is considered to influence on the lower limb joints kinematics and kinetics during SitTS movements, and thus suggests the possibility that of reducing the risks of pain, and osteoarthritis caused by changes in the loading of lower limb joints.

Keywords: Unstable shoes, Sit-to-stand, Lower limb joints

\section{서 론}

발은 신체와 외부 환경 사이의 접촉하는 첫 번째 지점으로, 중추 신 경계에 안정성과 이동을 위한 감각 정보를 제공하는데, ${ }^{1}$ 신발은 이러 한 발에서부터의 감각 피드백에 영향을 줄 수 있고, 발과 외부 환경 사이의 감각 필터로서 작용할 수도 있다.2-4

최근에 다양한 형태의 불안정성 신발(unstable shoe)이 기능적 또는 치료적 도구로 개발되고 있는데, ${ }^{5}$ 이러한 신발은 전-후 방향으로 둥 근 밑창을 부착하여 불안정성 지지면을 제공함으로써' 전-후 방향으 로의 외부 교란에 대한 균형은 엉덩이-발목 전략으로 알려진 근육 활 성화의 시너지 효과에 의해 수정되며, 균형과 자세를 개선시키는 목 적으로 사용되고 있다. ${ }^{5}$

불안정성 신발은 보행 및 서 있는 자세에서 하지의 근 활성도 패턴
에 변화를 줄 뿐만 아니라 운동형상학 및 운동역학적으로 변화를 생 성한다.5.89 신발 밑창에 의해 발생된 불안정성이 발목관절의 움직임 과 안정성에 직접적으로 영향을 미치고, ${ }^{10}$ 신체의 안정성이 관절 축에 서 먼 위치에 있는 큰 근육들(가자미근, 장딴지근 등)의 작용으로 유 지된다면, 관절에 가해지는 부하는 증가할 것이고, 관절 축에 가까이 위치하는 작은 근육들의 작용으로 안정성이 유지된다면 이러한 근 육들이 빠르게 반응할 수 있을 것이며, 관절 부하는 상당히 많이 감 소할 것이다. ${ }^{6}$ 이러한 신발 기능의 개념적인 측면에서 볼 때, 해부학적 으로 회전 축에 가까이 위치한 근육을 강화하는 것과 연관되어있다 고 보고되었다. ${ }^{6}$ 또한, 보행하는 동안 발뒤꿈치 닿기에서 발 끝 떼기까 지 발을 잡아주어 관절의 움직임을 줄여주고 앞쪽으로 덜 기울어지 게 함으로써 최적화된 신체정렬을 가능하게 하며, 하지의 모멘트 감 소로 관절에 가해지는 부하를 감소시켜준다.1112
Received Jan 12, 2016 Revised Feb 12, 2016

Accepted Feb 22, 2016

Corresponding author Ji-Won Park

E-mail mylovept@hanmail.net
Copylight (C) 2016 The Korea Society of Physical Therapy

This is an Open Access article distribute under the terms of the Creative Commons Attribution Non-commercial License (Http:// creativecommons.org/license/by-nc/3.0.) which permits unrestricted non-commercial use, distribution, and reproduction in any medium, provided the original work is properly cited. 
앉은 자세에서 일어서기(sit-to-stand)동작은 일상적인 움직임으 로, ${ }^{13}$ 가장 일반적으로 요구되는 기능적 과제이다.14 이러한 동작을 수 행하는 동안 하지 근육의 큰 힘과 넓은 범위의 관절 움직임이 포함되 어 있고, 상당한 균형의 과제와 관련되어 있으며, ${ }^{15}$ 특히 보행과 계단 오르기 동작보다 엉덩관절과 무릎관절의 큰 모멘트가 필요하다. ${ }^{16-18}$ 또한, 이러한 동작 수행 동안의 운동형상학적 및 동적 변수의 차이는 움직임의 실행 속도와 19,20 발목관절의 발등 굽힘 각도와 같은 시작자 세와 연관되어 있는데, ${ }^{21,22}$ 초기 앉은 자세가 변경될 때는 관련된 근 육들의 작용 패턴이 달라진다.23

인체의 관절에 적용되는 힘을 측정하고 이러한 힘이 주변 근육, 인 대, 관절면에 분배되는 방법을 측정하는 것은 관절 기능, 손상, 질병 을 이해하는 데 필수적이다. ${ }^{24}$ 하지만 앉은 자세에서 앉은 자세에서 일어서기 동작에 관한 선행 연구들을 살펴보면 주로 맨발 또는 다른 굽 높이의 신발 착용에 관한 연구들이 많았으며, ${ }^{25}$ 기능적 또는 치료 적 도구로서 개발되고 있는 다양한 형태의 불안정성 신발에 관한 선 행 연구들을 살펴보면 주로 서 있는 자세 ${ }^{26}$ 와 평지 보행에서 시행되었 으며,5,68 일상생활에서 가장 일반적으로 요구되는 기능적 과제 ${ }^{14}$ 인 앉 은 자세에서 앉은 자세에서 일어서기 동작 수행 동안 하지 관절의 운 동형상학 및 운동역학 변화에 관한 연구는 아직 미흡한 것으로 나타 났다.

따라서 본 연구는 앉은 자세에서 앉은 자세에서 일어서기 동작 수 행하는 동안 불안정성 신발 착용에 따른 하지 관절의 운동형상학 및 운동역학 변화를 분석하여, 임상에서 환자 평가와 치료중재 시 이에 관한 기초자료로 제시할 것이다.

\section{연구방법}

\section{1. 연구대상}

본 연구에서는 최근 1 년간 하지의 근골격계 이상, 선천적인 기형 및 정형 외과적 질환이나 변형, 신경학적으로 손상이 있는 자는 본 연구 에서 제외하였다. 실험에 참여한 대상자 모두 손을 사용하지 않고, 표 준 의자에서 독립적으로 앉고 일어설 수 있으며, ${ }^{27}$ 우성 발이 오른발 인 자(right-footed)로 차기 동작(kicking)을 수행할 때 사용하는 다리 로 오른쪽 다리를 선호하는 자로 선정했다. ${ }^{28}$ 실험하기 전, 전 과정에 대해 충분한 설명을 듣고 실험 참여에 자발적으로 동의를 한 대상자 들로 구성하였다.

\section{2. 실험방법}

1) 측정도구

(1) 하지의 관절 운동형상학 측정

3 차원 동작 분석기(Motion analysis corp, Santa rosa, CA, USA)는 8개의
적외선카메라로 구성되어있고, cortex motion capture software 1.1.4.386 프로그램을 이용하여 카메라 프레임 비율 $120 \mathrm{~Hz}$ 에서 기능 적인 동작을 수행하는 동안 대상자의 다리이음빼, 엉덩관절, 무릎관 절, 발목관절의 움직임을 측정하였다. 3 차원 동작 분석기의 표식자 (marker)는 Helen-Hayes Marker set 방법으로 부착하여 부착부위는 다음과 같다. 전상장골근(ASIS), 후상장골근(PSIS), 엉치뼈(sacrum), 넙다리(thigh), 안쪽 무릎(medial knee), 바깥쪽 무릎(lateral knee), 정강 이(shank), 안쪽 복사뼈(medial malleolus), 바깥쪽 복사뼈(lateral malleolus), 발뒤꿈치(heel), 두 번째와 세 번째 엄지 사이(toe)이다. 엉치뼈를 제외한 나머지 부위는 양쪽으로 부착하여 총 21 개의 표식자를 부착 하였다.

\section{(2) 불안정성신발(unstable shoes, US)}

불안정성신발은 전·후 방향으로 둥근 밑창의 형태를 가지며, 발 뒷굽 의 높이가 후방으로 좀 더 낮은 특성으로 불안정성 지면을 형성한다 (Figure 1).

\section{(3) 동작 별 제어 도구}

본 연구에 사용한 동작 별 제어 도구는 의자(chair)이다. 의자는 팔걸 이와 등받이가 없고, 의자 높이는 각각의 대상자마다 맨발로 앉았을 때 지면에서 넙다리외측과까지의 거리만큼 조절 하였다. ${ }^{26}$

\section{2) 실험절차}

본 실험에 참여한 대상자들은 실험 전 일반적인 특성 (나이, 신장, 체 중, 발 길이, 발 너비) 을 측정하고, 실험 전 편안한 속도대로 앉은 자세 에서 앉은 자세에서 일어서기 동작을 수행한 후 실험 시 조건 별 앉은 자세에서 앉은 자세에서 일어서기 동작을 3 번씩 반복 수행하였으며, 각 실험조건에서 앉은 자세에서 일어서기 동작의 수행 순서는 대상

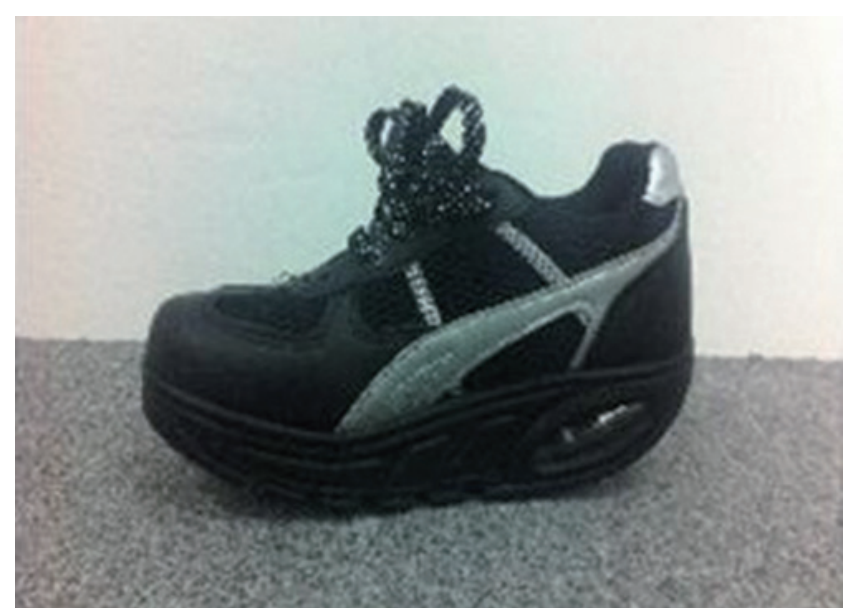

Figure 1. Unstable shoes. 
자마다 무작위 순서대로 진행하였다. 앉은 자세에서 일어서기 및 앉 는 동작 수행 시 대상자의 시작자세는 팔을 몸통에 교차해서 의자에 앉은 자세이다. 대상자는 청각적 신호를 들으면 앉은 자세에서 일어 서는 동작을 수행한다.25

본 연구에서 하지 관절의 운동형상학 및 운동역학적 자료는 앉은 자세에서 일어서기 동작을 수행하는 동안 각 동작의 초기 자세 시점, 동작 주기의 최대값, 마지막 자세 시점에서 얻은 하지 관절의 각도 (angle), 힘(force), 모멘트(moment)값이며,25 3 번씩 반복 측정에 대한 평 균값을 대표값으로 하여 통계 처리하였다.

\section{3. 통계 분석}

무릎관절의 평균 각도(angle), 힘(force), 모멘트(moment) 자료는 SIMM biomechanics software 6.0.2 프로그램으로 분석하였고, 통계처리는 PASW 18.0 프로그램을 이용하였다. 연구 대상자의 일반적인 특성은 기술통계량의 빈도분석으로 분석하였고, 앉은 자세에서 앉은 자세에 서 일어서기 동작 시 불안정성 신발의 착용 전과 후에 따른 하지 관절 의 운동형상학 및 운동역학 자료를 비교하기 위해 대응표본 $\mathrm{t}$ 검증 (paired t-test)을 사용하였다. 통계학적 유의수준 $\alpha=0.05$ 로 설정하였다.

\section{결 과}

\section{1. 연구 대상자의 일반적인 특성}

본 연구에 참여한 대상자는 여성 19명이며, 평균 나이 22.6세, 키 160.3 $\mathrm{cm}$, 체중 $50.2 \mathrm{~kg}$, 우성 발 길이 $23.5 \mathrm{~cm}$, 우성 발 너비 $9.0 \mathrm{~cm}$ 이었다.

\section{2. 하지 관절 각도(angle)}

1) 앉은 자세에서 앉은 자세에서 일어서기 동작 시 초기 자세 시점 앉은 자세에서 앉은 자세에서 일어서기 동작 시 초기 자세 시점에서 는 맨발보다 불안정성 신발 착용 시 엉덩관절과 무릎관절의 굽힘 각 도가 증가하였고, 발목관절의 발등 굽힘 각도는 감소하였으며, 모두 유의한차이가 있었다 $(\mathrm{p}<0.05)$ (Table 1).

\section{2) 앉은 자세에서 앉은 자세에서 일어서기 동작 시 마지막 자세 시점} 앉은 자세에서 앉은 자세에서 일어서기 동작 시 마지막 자세 시점에 서는 맨발보다 불안정성 신발 착용 시 엉덩관절과 무릎관절의 굽힘 각도는 유의한 차이가 없었으며, 발목관절의 발바닥 굽힘 각도는 증 가하였고, 모두 유의한 차이가 있었다 $(\mathrm{p}<0.05)($ Table 1$)$.

3) 앉은 자세에서 앉은 자세에서 일어서기 동작 수행 동안 굽힘 각도의 최대값

앉은 자세에서 앉은 자세에서 일어서기 동작 수행 동안 굽힘 각도의
Table 1. Sit-to-stand task of lower limbs angle (degree)

\begin{tabular}{llccc}
\hline $\begin{array}{c}\text { Sit-to-stand task } \\
\text { (event) }\end{array}$ & & BF & US & p \\
\hline Initial & Hip flexion & $65.94 \pm 6.07$ & $72.55 \pm 6.37$ & $0.000 *$ \\
& Knee flexion & $90.70 \pm 6.89$ & $97.54 \pm 5.28$ & $0.000 *$ \\
& Ankle flexion & $11.23 \pm 6.08$ & $5.93 \pm 5.86$ & $0.003 *$ \\
Terminal & Hip flexion & $6.23 \pm 6.69$ & $4.59 \pm 5.97$ & 0.069 \\
& Knee flexion & $-2.88 \pm 2.83$ & $-3.84 \pm 3.18$ & 0.126 \\
& Ankle flexion & $-5.56 \pm 4.33$ & $-12.47 \pm 2.40$ & $0.000 *$ \\
Maximal angle & Hip flexion & $89.29 \pm 4.49$ & $93.43 \pm 2.40$ & $0.001 *$ \\
& Knee flexion & $92.53 \pm 6.92$ & $100.14 \pm 5.13$ & $0.000 *$ \\
& Ankle flexion & $19.08 \pm 4.86$ & $22.69 \pm 4.31$ & $0.014 *$ \\
\hline
\end{tabular}

Values are mean $\pm S D$

$* \mathrm{p}<0.05$

BF: Barefoot group, US: Unstable shoes group.

최대값은 맨발보다 불안정성 신발 착용 시 엉덩관절과 무릎관절의 굽힘, 발목관절의 발등 굽힘 모두 증가하였고, 유의한 차이가 있었다 $(\mathrm{p}<0.05)$ (Table 1).

\section{3. 하지 관절 근육 힘(force)}

1) 앉은 자세에서 앉은 자세에서 일어서기 동작 시 초기 자세 시점 앉은 자세에서 앉은 자세에서 일어서기 동작 시 초기 자세 시점에서 는 맨발과 불안정성 신발 착용에 따른 큰볼기근의 힘은 증가하면서 유의한 차이가 있었다 $(\mathrm{p}<0.05)$. 엉덩근과 큰허리근의 힘에서는 감소 하면서 유의한 차이가 있었다 $(\mathrm{p}<0.05)$. 반막근과 반힘줄근의 힘은 증 가하면서 유의한 차이가 있었지만 $(\mathrm{p}<0.05)$, 넙다리두갈래근의 긴 갈 래와 넙다리곧은근의 힘은 유의한 차이가 없었다. 맨발과 불안정성 신발 착용에 따른 중간넓은근과 안쪽넓은근, 가쪽넓은근의 힘은 감 소하면서 유의한 차이가 있었고 $(\mathrm{p}<0.05)$, 안쪽장딴지근과 가쪽장딴 지근, 가자미근의 힘도 불안정성 신발 착용 시 모두 감소하면서 유의 한 차이가 있었다 $(\mathrm{p}<0.05)$. 맨발과 불안정성 신발 착용에 따른 앞정 강근의 힘은 유의한 차이가 없었다(Table 2).

\section{2) 앉은 자세에서 앉은 자세에서 일어서기 동작 시 마지막 자세 시점} 앉은 자세에서 앉은 자세에서 일어서기 동작 시 마지막 자세 시점에 서는 맨발과 불안정성 신발 착용에 따른 큰볼기근의 힘은 감소하면 서 유의한 차이가 있었고 $(\mathrm{p}<0.05)$, 엉덩근과 큰허리근의 힘도 감소하 면서 유의한 차이가 있었다 $(\mathrm{p}<0.05)$. 반막근과 반힘줄근의 힘은 유의 한 차이가 없었지만, 넙다리두갈래근의 긴 갈래의 힘은 감소하면서 유의한 차이가 있었다 $(\mathrm{p}<0.05)$. 맨발과 불안정성 신발 착용에 따른 넙다리곧은근과 중간넓은근, 가쪽넓은근의 힘은 유의한 차이가 없 었지만, 안쪽넓은근의 힘은 감소하면서 유의한 차이가 있었다 $(\mathrm{p}<0.05)$. 안쪽장딴지근과 가쪽장딴지근, 가자미근의 힘은 불안정성 
Table 2. Sit-to-stand task of lower limbs muscle force (force)

\begin{tabular}{|c|c|c|c|c|}
\hline $\begin{array}{l}\text { Sit-to-stand } \\
\text { task (event) }\end{array}$ & Muscle & $\mathrm{BF}$ & US & $\mathrm{p}$ \\
\hline \multirow[t]{14}{*}{ Initial } & glut_max & $308.34 \pm 12.59$ & $316.16 \pm 13.21$ & $0.002 *$ \\
\hline & iliacus & $358.43 \pm 35.62$ & $335.04 \pm 42.95$ & $0.015 *$ \\
\hline & Psoas & $332.88 \pm 16.89$ & $325.81 \pm 17.33$ & $0.003 *$ \\
\hline & semimem & $505.36 \pm 189.02$ & $585.88 \pm 135.05$ & $0.037 *$ \\
\hline & semiten & $295.61 \pm 16.85$ & $297.33 \pm 18.53$ & $0.034 *$ \\
\hline & bi_fem_lh & $583.71 \pm 53.23$ & $599.37 \pm 32.80$ & 0.199 \\
\hline & rectus_fem & $669.78 \pm 66.43$ & $653.94 \pm 72.68$ & 0.125 \\
\hline & vas_med & $1,124.40 \pm 59.25$ & $1,091.41 \pm 60.19$ & $0.000 *$ \\
\hline & vas_int & $1,163.77 \pm 69.07$ & $1,126.84 \pm 71.20$ & $0.000 *$ \\
\hline & vas_lat & $1,598.05 \pm 82.69$ & $1,545.59 \pm 85.31$ & $0.000 *$ \\
\hline & gas_med & $47.83 \pm 38.91$ & $4.21 \pm 4.87$ & $0.000 *$ \\
\hline & gas_lat & $110.96 \pm 36.08$ & $47.07 \pm 18.94$ & $0.000 *$ \\
\hline & soleus & $1,572.50 \pm 327.60$ & $1,181.90 \pm 393.47$ & $0.000 *$ \\
\hline & tib_ant & $373.03 \pm 58.03$ & $398.30 \pm 50.17$ & 0.087 \\
\hline \multirow[t]{14}{*}{ Terminal } & glut_max & $35.64 \pm 36.01$ & $25.28 \pm 29.22$ & $0.026 *$ \\
\hline & iliacus & $379.01 \pm 14.32$ & $375.55 \pm 14.71$ & $0.022 *$ \\
\hline & Psoas & $310.88 \pm 14.26$ & $308.06 \pm 14.52$ & $0.045 *$ \\
\hline & semimem & $483.10 \pm 160.16$ & $456.61 \pm 126.12$ & 0.147 \\
\hline & semiten & $296.67 \pm 18.69$ & $296.46 \pm 18.13$ & 0.424 \\
\hline & bi_fem_lh & $589.60 \pm 48.62$ & $582.06 \pm 39.99$ & $0.028 *$ \\
\hline & rectus_fem & $547.38 \pm 95.23$ & $556.97 \pm 80.26$ & 0.367 \\
\hline & vas_med & $1,190.64 \pm 76.94$ & $1,190.68 \pm 77.11$ & 0.209 \\
\hline & vas_int & $1,260.44 \pm 83.28$ & $1,260.23 \pm 82.20$ & $0.008 *$ \\
\hline & vas_lat & $1,720.66 \pm 110.49$ & $1,720.57 \pm 110.46$ & 0.207 \\
\hline & gas_med & $586.88 \pm 97.71$ & $408.01 \pm 67.21$ & $0.000 *$ \\
\hline & gas_lat & $358.77 \pm 28.27$ & $307.54 \pm 28.77$ & $0.000 *$ \\
\hline & soleus & $527.97 \pm 279.01$ & $145.75 \pm 79.93$ & $0.000 *$ \\
\hline & tib_ant & $471.64 \pm 23.76$ & $482.54 \pm 23.11$ & $0.001 *$ \\
\hline \multirow[t]{14}{*}{ Maximal force } & glut_max & $329.11 \pm 10.83$ & $325.40 \pm 22.32$ & 0.503 \\
\hline & iliacus & $404.06 \pm 13.45$ & $404.04 \pm 13.46$ & 0.538 \\
\hline & Psoas & $349.30 \pm 12.12$ & $349.34 \pm 12.11$ & 0.253 \\
\hline & semimem & $861.00 \pm 46.00$ & $861.80 \pm 48.29$ & 0.926 \\
\hline & semiten & $299.48 \pm 18.95$ & $299.53 \pm 18.97$ & 0.104 \\
\hline & bi_fem_lh & $654.99 \pm 41.87$ & $656.35 \pm 40.53$ & 0.454 \\
\hline & rectus_fem & $676.35 \pm 59.69$ & $664.84 \pm 54.12$ & 0.096 \\
\hline & vas_med & $1,190.64 \pm 76.94$ & $1,190.68 \pm 77.11$ & 0.620 \\
\hline & vas_int & $1,160.44 \pm 83.28$ & $1,260.23 \pm 83.20$ & $0.008 *$ \\
\hline & vas_lat & $1,720.66 \pm 110.49$ & $1,720.57 \pm 110.46$ & 0.420 \\
\hline & gas_med & $589.24 \pm 97.97$ & $424.51 \pm 68.84$ & $0.000 *$ \\
\hline & gas_lat & $359.29 \pm 28.30$ & $311.80 \pm 28.50$ & $0.000 *$ \\
\hline & soleus & $1,932.01 \pm 165.23$ & $1,999.10 \pm 131.11$ & 0.055 \\
\hline & tib_ant & $470.32 \pm 23.68$ & $483.45 \pm 23.11$ & $0.000 *$ \\
\hline
\end{tabular}

Values are mean $\pm S D$.

$* \mathrm{p}<0.05$.

BF: Barefoot group, US: Unstable shoes group

Glut_max: Gluteus maximus, lliacus: lliacus, Psoas: Psoas major \& minor, Semimem: Semimembranosus, Semiten: Semitendinosus, Bi_fem_lh: Biceps femoris (long head), Vas_med: Vastus medialis, Vas_int: Vastus intermedius, Vas_lat: Vastus lateralis, Gas_med: Gastrocnemius (medial part), Gas_lat: Gastrocnemius (lateral part), Soleus: Soleus, Tib ant: Tibialis anterior.
신발 착용 시 모두 감소하면서 유의한 차이가 있었지만 $(\mathrm{p}<0.05)$, 앞정 강근의 힘은 불안정성 신발 착용 시 증가하면서 유의한 차이가 있었 다 $(\mathrm{p}<0.05)$ (Table 2$)$.

\section{3) 동작 수행 동안 힘의 최대값}

앉은 자세에서 앉은 자세에서 일어서기 동작 수행 동안 힘의 최대값 에서는 맨발과 불안정성 신발 착용에 따른 큰볼기근과 엉덩근과 큰 허리근의 힘은 유의한 차이가 없었다. 반막근과 반힘줄근, 넙다리두 갈래근의 긴 갈래의 힘도 불안정성 신발 착용 시 유의한 차이가 없었 다. 맨발과 불안정성 신발 착용에 따른 넙다리곧은근과 중간넓은근, 가쪽넓은근의 힘은 유의한 차이가 없었지만, 안쪽넓은근의 힘은 증 가하면서 유의한 차이가 있었다 $(\mathrm{p}<0.05)$. 안쪽장딴지근과 가쪽장딴 지근의 힘은 불안정성 신발 착용 시 모두 감소하면서 유의한 차이가 있었지만 $(\mathrm{p}<0.05)$, 가자미근은 유의한 차이가 없었다. 앞정강근의 힘 은 불안정성 신발 착용 시 증가하면서 유의한 차이가 있었다 $(\mathrm{p}<0.05)$ (Table 2)

\section{4. 하지 관절 모멘트(moment)}

1) 앉은 자세에서 앉은 자세에서 일어서기 동작 시 초기 자세 시점 앉은 자세에서 앉은 자세에서 일어서기 동작 시 초기 자세 시점에서 는 맨발과 불안정성 신발 착용에 따른 큰볼기근의 내부 엉덩관절 폄 근 모멘트에서는 감소하면서 유의한 차이가 있었으며 $(\mathrm{p}<0.05)$, 엉덩 근과 큰허리근의 내부 엉덩관절 굽힘근 모멘트에서도 감소하면서 유 의한차이가 있었다 $(\mathrm{p}<0.05)$.

맨발과 불안정성 신발 착용에 따른 반막근과 넙다리두갈래근의 긴 갈래의 내부 무릎관절 굽힘근 모멘트에서는 유의한 차이가 없었 지만, 반힘줄근의 내부 무릎관절 굽힘근 모멘트 에서는 감소하면서 유의한차이가 있었다 $(\mathrm{p}<0.05)$. 불안정성 신발 착용시 넙다리곧은근 과 중간넓은근, 안쪽넓은근과 가쪽넓은근의 내부 무릎관절 폄근 모 멘트는 모두 감소하면서 유의한 차이가 있었다 $(\mathrm{p}<0.05)$.

맨발과 불안정성 신발 착용에 따른 안쪽장딴지근과 가쪽장딴지 근, 가자미근의 내부 발목관절 발바닥 굽힘 모멘트는 모두 감소하면 서 유의한 차이가 있었지만( $\mathrm{p}<0.05)$, 앞정강근의 내부 발목관절 발등 굽힘 모멘트는 증가하면서 유의한 차이가 있었다( $\mathrm{p}<0.05)$ (Table 3).

2) 앉은 자세에서 앉은 자세에서 일어서기 동작 시 마지막 자세 시점 앉은 자세에서 앉은 자세에서 일어서기 동작 시 마지막 자세 시점에 서는 맨발과 불안정성 신발 착용에 따른 큰볼기근의 내부 엉덩관절 폄근 모멘트에서는 감소하면서 유의한 차이가 있었으며 $(\mathrm{p}<0.05)$, 엉 덩근과 큰허리근의 내부 엉덩관절 굽힘근 모멘트에서도 감소하면서 유의한차이가 있었다 $(\mathrm{p}<0.05)$. 
Table 3. Sit-to-stand task of lower limbs muscle moment (moment)

\begin{tabular}{|c|c|c|c|c|}
\hline $\begin{array}{l}\text { Sit-to-stand } \\
\text { task (event) }\end{array}$ & Muscle & BF & US & $\mathrm{p}$ \\
\hline \multirow[t]{14}{*}{ Initial } & glut_max & $-7.97 \pm 1.33$ & $-7.34 \pm 1.09$ & 0.009 * \\
\hline & iliacus & $15.50 \pm 1.89$ & $14.52 \pm 2.06$ & $0.032 *$ \\
\hline & Psoas & $12.81 \pm 1.22$ & $12.29 \pm 1.20$ & $0.015 *$ \\
\hline & semimem & $16.35 \pm 6.75$ & $16.65 \pm 3.93$ & 0.807 \\
\hline & semiten & $9.37 \pm 1.06$ & $8.29 \pm 0.80$ & $0.000 *$ \\
\hline & bi_fem_lh & $28.50 \pm 2.89$ & $28.59 \pm 2.13$ & 0.889 \\
\hline & rectus_fem & $-15.42 \pm 2.08$ & $-14.50 \pm 2.26$ & $0.001 *$ \\
\hline & vas_med & $-28.17 \pm 3.51$ & $-26.85 \pm 3.23$ & $0.014 *$ \\
\hline & vas_int & $-27.19 \pm 3.57$ & $-25.79 \pm 3.10$ & $0.005 *$ \\
\hline & vas_lat & $-38.89 \pm 3.96$ & $-35.85 \pm 3.66$ & $0.000 *$ \\
\hline & gas_med & $-1.36 \pm 1.03$ & $-0.12 \pm 0.14$ & $0.000 *$ \\
\hline & gas_lat & $-3.27 \pm 0.91$ & $-1.45 \pm 0.54$ & $0.000 *$ \\
\hline & soleus & $-44.12 \pm 7.08$ & $-34.95 \pm 10.48$ & $0.001 *$ \\
\hline & tib_ant & $12.20 \pm 2.03$ & $13.35 \pm 1.74$ & $0.018 *$ \\
\hline \multirow[t]{14}{*}{ Terminal } & glut_max & $-1.50 \pm 1.44$ & $-1.08 \pm 1.18$ & $0.028 *$ \\
\hline & iliacus & $11.05 \pm 1.23$ & $10.70 \pm 1.09$ & $0.035 *$ \\
\hline & Psoas & $8.62 \pm 0.96$ & $8.37 \pm 0.83$ & $0.049 *$ \\
\hline & semimem & $9.14 \pm 3.05$ & $8.32 \pm 2.50$ & 0.076 \\
\hline & semiten & $7.47 \pm 0.85$ & $7.21 \pm 0.74$ & 0.065 \\
\hline & bi_fem_lh & $4.21 \pm 1.49$ & $3.55 \pm 1.67$ & 0.065 \\
\hline & rectus_fem & $-27.50 \pm 5.31$ & $-28.04 \pm 4.80$ & 0.292 \\
\hline & vas_med & $-7.24 \pm 3.13$ & $-6.16 \pm 3.61$ & 0.163 \\
\hline & vas_int & $-8.03 \pm 3.47$ & $-6.82 \pm 4.01$ & 0.162 \\
\hline & vas_lat & $-9.06 \pm 4.26$ & $-7.64 \pm 5.06$ & 0.188 \\
\hline & gas_med & $-18.85 \pm 2.96$ & $-13.32 \pm 2.12$ & $0.000 *$ \\
\hline & gas_lat & $-11.81 \pm 0.93$ & $-10.30 \pm 0.98$ & $0.000 *$ \\
\hline & soleus & $-16.71 \pm 8.56$ & $-4.78 \pm 2.52$ & $0.000 *$ \\
\hline & tib_ant & $15.13 \pm 1.25$ & $15.32 \pm 1.23$ & 0.001 * \\
\hline \multirow[t]{14}{*}{ Maximal moment } & glut_max & $-1.38 \pm 1.13$ & $-1.03 \pm 1.07$ & $0.038 *$ \\
\hline & iliacus & $16.17 \pm 1.16$ & $16.14 \pm 1.21$ & 0.714 \\
\hline & Psoas & $13.30 \pm 0.90$ & $13.27 \pm 0.94$ & 0.699 \\
\hline & semimem & $32.31 \pm 2.99$ & $32.07 \pm 3.27$ & 0.653 \\
\hline & semiten & $12.83 \pm 1.39$ & $12.86 \pm 1.35$ & 0.331 \\
\hline & bi_fem_lh & $32.50 \pm 3.18$ & $32.50 \pm 3.33$ & 0.999 \\
\hline & rectus_fem & $-10.04 \pm 4.23$ & $-9.21 \pm 3.31$ & 0.140 \\
\hline & vas_med & $-7.23 \pm 3.13$ & $-6.15 \pm 3.60$ & 0.166 \\
\hline & vas_int & $-8.02 \pm 3.49$ & $-7.18 \pm 4.15$ & 0.331 \\
\hline & vas_lat & $-9.04 \pm 4.27$ & $-7.63 \pm 5.04$ & 0.190 \\
\hline & gas_med & $-1.28 \pm 1.02$ & $-0.09 \pm 0.11$ & $0.000 *$ \\
\hline & gas_lat & $-3.18 \pm 0.93$ & $-1.35 \pm 0.49$ & $0.000 *$ \\
\hline & soleus & $-16.48 \pm 8.54$ & $-4.53 \pm 2.31$ & $0.000 *$ \\
\hline & tib_ant & $15.10 \pm 1.30$ & $15.37 \pm 1.24$ & $0.000 *$ \\
\hline
\end{tabular}

Values are mean \pm SD

$* \mathrm{p}<0.05$.

BF: Barefoot group, US: Unstable shoes group, Glut_max: Gluteus maximus, lliacus: lliacus, Psoas: Psoas major \& minor, Semimem: Semimembranosus, Semiten: Semitendinosus, Bi_fem_Ih: Biceps femoris (long head), Vas_med: Vastus medialis, Vas_int: Vastus intermedius, Vas_lat: Vastus lateralis, Gas_med: Gastrocnemius (medial part), Gas_lat: Gastrocnemius (lateral part), Soleus: Soleus, Tib_ant: Tibialis anterior.
맨발과 불안정성 신발 착용에 따른 반막근과 반힘줄근, 넙다리두 갈래근의 긴 갈래의 내부 무릎관절 굽힘근 모멘트에서는 유의한 차 이가 없었고, 넙다리곧은근과 중간넓은근, 안쪽넓은근과 가쪽넓은 근의 내부 무릎관절 폄근 모멘트도 모두 유의한 차이가 없었다.

맨발과 불안정성 신발 착용에 따른 안쪽장딴지근과 가쪽장딴지 근, 가자미근의 내부 발목관절 발바닥 굽힘 모멘트는 모두 감소하면 서 유의한 차이가 있었지만 $(\mathrm{p}<0.05)$, 앞정강근의 내부 발목관절 발등 굽힘 모멘트는 증가하면서 유의한 차이가 있었다 $(\mathrm{p}<0.05)($ Table 3).

\section{3) 동작 수행 동안 내부 모멘트의 최대값}

앉은 자세에서 앉은 자세에서 일어서기 동작 수행 동안 내부 모멘트 의 최대값은 맨발과 불안정성 신발 착용에 따른 큰볼기근의 내부 엉 덩관절 폄근 모멘트는 감소하면서 유의한 차이가 있었고 $(\mathrm{p}<0.05)$, 엉 덩근과 큰허리근의 내부 엉덩관절 굽힘근 모멘트에서는 유의한 차이 가 없었다.

맨발과 불안정성 신발 착용에 따른 반막근과 반힘줄근, 넙다리두 갈래근의 긴 갈래의 내부 무릎관절 굽힘근 모멘트에서는 유의한 차 이가 없었고, 넙다리곧은근과 중간넓은근, 안쪽넓은근과 가쪽넓은 근의 내부 무릎관절 폄근 모멘트도 유의한 차이가 없었다.

맨발과 불안정성 신발 착용에 따른 안쪽장딴지근과 가쪽장딴지 근, 가자미근의 내부 발목관절 발바닥 굽힘 모멘트는 모두 감소하면 서 유의한차이가 있었지만 $(\mathrm{p}<0.05)$, 앞정강근의 내부 발목관절 발등 굽힘 모멘트는 증가하면서 유의한 차이가 있었다 $(\mathrm{p}<0.05)($ Table 3).

\section{고 찰}

본 연구는 앉은 자세에서 일어서기 동작 시 불안정성 신발 착용에 따 른 하지 관절의 운동형상학 및 운동역학적인 변화를 알아보기 위해 3 차원 동작 분석 시스템을 통해 측정 및 분석을 하였다.

불안정성 신발은 다양한 형태로의 기능적 또는 치료적 도구로 개 발되고 있는데, ${ }^{5}$ 전-후 방향의 둥근 밑창으로 인해 불안정성 지지면 을 제공함으로써, 보행 및 서 있는 자세에서 하지의 근 활성도 패턴에 변화를 줄 뿐만 아니라 운동형상학 및 운동역학적으로 변화를 생성 한다. ${ }^{5,89}$ 이와 관련된 선행연구가 많이 이루어지고 있음에도 불구하 고, 일상생활에서 가장 일반적으로 요구되는 기능적 과제 ${ }^{14}$ 인 앉은 자 세에서 일어서기 동작 시 불안정성 신발 착용에 따른 하지 관절의 운 동형상학 및 운동역학적인 관점의 연구는 아직 미흡한 것으로 나타 났다. 이에 본 연구는 불안정성 신발 착용 시 하지 관절의 각도(angle), 모멘트(moment), 힘(force)을 앉은 자세에서 일어서기 동작의 해당시 점에 따라알아보고자 하였다.

앉은 자세에서 일어서기 동작은 수행하는 동안 넓은 범위의 하지 
관절 움직임이 포함되어 있다. ${ }^{15}$ 본 연구 결과에서는 동작 초기 자세 시점과 굽힘 각도의 최대값에서 맨발보다 불안정성 신발 착용 시 엉 덩관절과 무릎관절의 움직임이 증가하였고, 발목관절의 움직임은 동작 초기 자세 시점과 마지막 자세 시점에서 발바닥 굽힘의 움직임 이 상대적으로 증가하였으며, 굽힘 각도의 최대값에서는 발등 굽힘 의 움직임이 증가하였다. 보행 시 불안정성 신발이 발뒤꿈치 닿기에 서 발 끝 떼기까지 발을 잡아주어 관절의 움직임을 줄여주고 앞쪽으 로 덜 기울어지게 함으로써 최적화된 신체정렬을 가능하게 한다는 선행연구 ${ }^{11,12}$ 와는 달리 일어서기 동작 시에는 하지 관절의 움직임이 증가하였음을 알 수 있다. 이는 움직임의 실행 속도와 19,20 신발 밑창에 의해 발생된 불안정성이 동작 수행 동안의 상당한 균형을 조절하기 위해 발목관절의 움직임과 안정성에 직접적으로 영향을 미치며, ${ }^{10,15}$ 이러한 상반된 결과의 운동형상학적 및 동적 변수 차이를 나타낸 것 으로 생각된다.

또한, 이러한 동작은 보행 및 계단보행과 비교했을 때 보다 더 큰 관 절의 힘과 모멘트가 필요한데, 이는 일어서는 능력을 결정하는 것으 로 엉덩관절과 무릎관절 폄근이 중요한 역할을 한다. ${ }^{16}$ 엉덩관절에 가 로지르는 힘은 엉덩관절 통증의 원인이 될 수 있는데, 엉덩관절의 비 정상적인 또는 과도하게 가해지는 부하는 엉덩관절의 앞쪽 통증과 감지하기 힘든 불안정성의 잠재적인 원인으로 인식되고 있다.29 엉덩 관절의 불안정성과 과도한 힘은 외상성 결여로 관골구 순의 파열을 야기시킬 수 있으며, 29.32 엉덩관절의 불안정성, 앞쪽 통증, 비구 관절 순의 파열을 갖고 있는 사람은 엉덩관절을 움직일 때 통증이 나타난 다고 보고되었다. ${ }^{33}$ 본 연구 결과에서는 동작 시 초기 자세 시점에서 불안정성 신발 착용 시 큰 볼기근의 힘은 증가하였지만, 엉덩근과 큰 허리근의 힘에서는 감소하였고, 큰볼기근의 내부 엉덩관절 폄근 모멘 트와 엉덩근, 큰허리근의 내부 엉덩관절 굽힘근 모멘트 모두 감소하 였다. 마지막 자세 시점에서도 큰볼기근과 엉덩근, 큰허리근의 힘이 감소하였다. 큰 볼기근의 내부 엉덩관절 폄근 모멘트와 엉덩근, 큰허 리근의 내부 엉덩관절 굽힘근 모멘트에서도 감소하였으며, 동작 수행 동안 내부 모멘트의 최대값은 큰볼기근의 내부 엉덩관절 폄근 모멘 트가 감소하였다. 신체의 안정성이 관절 축에서 먼 위치에 있는 큰 근 육들의 작용으로 유지된다면, 관절에 가해지는 부하는 증가할 것이 다라고 보고하였는데, ${ }^{6}$ 큰 근육들의 작용이 감소된다면, 관절 부하는 상당히 많이 감소할 것이며, ${ }^{6}$ 이러한 결과는 엉덩관절에 가해지는 부 하를 감소시킬 수 있을 것이다. 또한, 관절 통증은 관절 부하와 연관 되어 있고, 관절 부하 감소는 관절 통증을 감소시켜줄 것이라고 보고 되고 있으며, ${ }^{6}$ 불안정성 신발 착용이 엉덩관절 앞쪽 통증과 불안정성 이 있는 환자의 통증 감소에 기여할 수 있을 것이라 생각된다. 이러한 엉덩관절의 힘을 이해하는 것은 재활치료 결과를 향상시킬 수 있을 것이며, ${ }^{2}$ 치료적 방향 또한 제시해줄 수 있을 것이라 생각된다.
무릎관절염 환자의 뒤넙다리근군(hamstring group) 활성도 증가는 압축력을 증가시킴으로써 지지기 동안 슬관절 안정화, 부하의 원심 성 조절, 인대의 보호를 향상시킨다. ${ }^{34-36}$ 본 연구결과에서는 앉은 자세 에서 앉은 자세에서 일어서기 동작 시 초기 자세 시점에서는 불안정 성 신발 착용 시 반막근과 반힘줄근의 힘은 증가한 것으로 보아, 동작 의 초기 자세 시점에서 슬관절 안정화 및 부하의 원심성 조절 등을 향상시킬 수 있을 것이라 생각된다.

굽힘 모멘트에 영향을 주는 신발 또는 신발 깔창은 외부 무릎관절 모음 모멘트와 모음 각도 충격량(angular impulse)에 영향을 줄 수 있 는데, ${ }^{37}$ 불안정성 신발은 하지의 모멘트 감소로 관절에 가해지는 부하 를 감소시켜주며, ${ }^{12}$ 다른 선행연구에서도 과체중인 남성이 불안정성 신발의 한 형태인 'MBT' 신발을 착용했을 때 첫 번째 최대 외부 모음 모멘트에서 $12 \%$ 감소되었다. ${ }^{38}$ 본 연구 결과에서도 동작 초기 자세 시 점의 중간넓은근과 안쪽넓은근, 가쪽넓은근 힘과 반힘줄근의 내부 무릎관절 굽힘근 모멘트가 감소하였고, 넙다리곧은근과 중간넓은 근, 안쪽넓은근과 가쪽넓은근의 내부 무릎관절 폄근 모멘트가 모두 감소하였다. 또한 마지막 자세 시점에서는 넙다리두갈래근의 긴 갈래 와 안쪽넓은근의 힘은 감소하였다. 이러한 결과 불안정성 신발 착용 이 무릎넙다리관절의 부하 변화에 영향을 미칠 수 있을 것이며, 가해 지는 스트레스를 감소시켜줄 수 있을 것이라 생각된다. 더군다나, 관 절염 통증이 있는 환자는 불안정성 신발의 한 형태인 ' $\mathrm{MBT}$ '신발을 착 용하여 보행을 했을 때 통증이 감소되었으며, ${ }^{6}$ 본 연구의 결과에서도 앉은 자세에서 일어서기 동작 시 무릎 통증 감소에 기여할 수 있을 것 이라 생각된다.

발목관절의 운동 변화는 하지 관절이 닫힌 운동사슬로 연결되어 있기 때문에 다른 하지 관절의 움직임에 영향을 주게 된다. 최근에 기 능성 혹은 치료적인 도구로 다양한 형태로 개발되고 있는 불안정성 신발은 전·후 방향이 둥근 밑창으로 발목의 움직임에 변화를 유발시 키는데, ${ }^{8}$ 서 있는 동안 일반 신발을 착용했을 때보다 불안정성 신발 을 착용했을 때 앞정강근의 증가가 나타났다. ${ }^{6}$ 본 연구결과에서는 동 작 시 초기 자세 시점에서 안쪽장딴지근과 가쪽장딴지근, 가자미근 의 힘과 내부 발목관절 발바닥 굽힘 모멘트가 모두 감소하였고, 앞정 강근의 내부 발목관절 발등 굽힘 모멘트는 증가하였다. 마지막 자세 시점에서는 안쪽장딴지근과 가쪽장딴지근, 가자미근의 힘과 안쪽장 딴지근과 가쪽장딴지근, 가자미근의 내부 발목관절 발바닥 굽힘 모 멘트는 불안정성 신발 착용 시 모두 감소하였고, 앞정강근의 힘과 내 부 발목관절 발등 굽힘 모멘트는 증가하였다. 앉은 자세에서 앉은 자 세에서 일어서기 동작 수행 동안 최대값에서는 안쪽장딴지근과 가 쪽장딴지근의 힘과 안쪽장딴지근과 가쪽장딴지근, 가자미근의 내부 발목관절 발바닥 굽힘 모멘트는 모두 감소하였고, 앞정강근의 힘과 앞정강근의 내부 발목관절 발등 굽힘 모멘트는 증가하였다. 또한, 일 
반적으로 여성이 남성보다 발등 굽힘의 최대 수의적 등척성 힘이 적 다. 게다가, 남성보다 발등 굽힘의 목표 토크에 도달하는 시간이 추가 적으로 더 많이 필요하다. ${ }^{39}$ 본 연구에서 건강한 여성을 대상으로 동 작을 수행하였고, 발등 굽힘 작용을 하는 앞정강근의 힘과 모멘트가 증가하였으며 이러한 결과는 특히, 여성의 발등 굽힘 강화 훈련에 긍 정적인 영향을 미칠 수 있을 것이라 생각된다.

그러나 본 연구는 실험에 참여한 대상자의 수도 적었으며, 대상자 선정기준을 두어 다소 어려움이 있어 정상 성인 여성으로 제한을 두 었다. 그리하여 향후 연구에서는 더 많은 대상자들로 하여금 더 다양 하한 굽 형태의 신발 중재를 적용하여 근 동원 및 균형에 중점을 두 어 이러한 변화 차이가 하지 관절의 운동형상학 및 운동역학에 어떠 한 영향을 미치는지를 제시할 것이다.

본 연구는 앉은 자세에서 일어서기 동작 시 발목관절의 자세변화 와 무릎관절, 엉덩관절 움직임 및 부하의 관련성에 대한 운동형상학 및 운동역학적 기초자료를 제공하는데 의의를 두고자 하였으며, 불 안정성 신발 착용이 엉덩관절 앞쪽 통증과 불안정성이 있는 환자와 무릎관절염 환자들에게 통증을 줄여줄 수 있다는 것과 발목관절의 불안정성, 근력 약화가 있는 환자들의 안정성 강화훈련의 치료중재 도구의 가능성을 제시할 수 있다고 생각된다.

\section{ACKNOWLEDGEMENTS}

This work was supported by research grants from the Catholic University of Daegu in 2012.

\section{REFERENCES}

1. Wilson ML, Rome K, Hodgson D et al. Effect of textured foot orthotics on static and dynamic postural stability in middle-aged females. Gait Posture. 2008;27(1):36-42.

2. Arnadottir SA, Mercer VS. Effects of footwear on measurements of balance and gait in women between the ages of 65 and 93 years. Phys Ther. 2000;80:17-27.

3. Mu“ndermann A, Stefanyshyn DJ, Nigg BM. Relationship between footwear comfort of shoe inserts and anthropometric and sensory factors. Med Sci Sports Exerc. 2001;33:1939-45.

4. Waddington G, Adams R. Textured insole effects on ankle movement discrimination while wearing athletic shoes. Phys Ther Sport. 2000;1: 119-28.

5. Nigg BM, G KE, Federolf P, Landry SC. Gender differences in lower extremity gait biomechanics during walking using an unstable shoe. Clin Biomech (Bristol, Avon). 2010;25(10):1047-52.

6. Nigg B, Hintzen S, Ferer R. Effect of an unstable shoe construction on lower extremity gait characteristics. Clin Biomech (Bristol, Avon). 2006; 21(1):82-8.
7. Gatev P, Thomas S, Kepple T et al. Feedforward strategy of balance during quiet stance in adults. J Physiol. 1999;514(3):915-28.

8. Romkes J, Rudmann C, Brunner R. Changes in gait and EMG when walking with the Masai Barefoot Technique. Clin Biomech Bristol Avon. 2006;21(1):75-81.

9. Taniguchi M, Tateuchi H, Takeoka T et al. Kinematic and kinetic characteristics of Masai Barefoot Technology footwear. Gait Posture. 2012; 35(4):567-72.

10. Robinovitch SN, Heller B, Lui A et al. Effect of strength and speed of torque development on balance recovery with the ankle strategy. J Neurophysiol. 2002 Aug;88(2):613-20.

11. Janisse DJ, Janisse E. Shoe modification and the use of orthoses in the treatment of foot and ankle pathology. J Am Acad Orthop Surg. 2008; 16(3):152-8.

12. Vernon T, Wheat J, Naik R et al. Change in Gait characteristics of a normal, healthy population due to an unstable shoe construction. Sheffiled Hallam U. UK. 2004.

13. Shin HK, Ryu YU. The effects of seat surface inclination on the onset of muscle contraction during sit-to-stand in healthy adults. J Kor Soc Phys Ther. 2012;24(6):383-7.

14. Park MC, Lee MH. Analysis of muscle activity on foot position during a sit-to-stand activity in the elderly. J Kor Soc Phys Ther. 2011;23(1):1-5.

15. Riley PO, Schenkman ML, Mann RW, Hodge WA. Mechanics of a constrained chair-rise. J Biomech. 1991;24(1):77-85.

16. Su FC, Lai KA, Hong WH. Rising from chair after total knee arthroplasty. Clin Biomech (Bristol Avon). 1998;13(3):176-81.

17. Wretenberg P, Aborelius UP. Power and work produced in different leg muscle groups when rising from a chair. Eur J Appl Physiol Occup Physiol. 1994;68(5):413-7.

18. Kotake, T, Dohi N, Kajiwara T et al. An analysis of sit-to-stand movements. Arch Phys Med Rehab. 1993;74(10):1095-9.

19. Pai YC, Rogers MW. Control of body mass transfer as a function of speed of ascent in sit-to-stand. Med Sci Sports Exerc. 1990;22(3):378-84.

20. Papa E, Cappozzo A. A telescopic inverted-pendulum model of the musculo-skeletal system and its use for the analysis of the sit-to-stand motor task. J Biomech. 1999;32(11):1205-12.

21. Fleckenstein SJ, Kirby RL, MacLeod DA. Effect of limited knee-flexion range on peak hip moments of force while transferring from sitting to standing. J Biomech. 1988;21(11):915-8.

22. Vander Linden DW, Brunt D, McCulloch MU. Variant and invariant characteristics of the sit-to-stand task in healthy elderly adults. Arch Phys Med Rehabil. 1994;75(6):653-60.

23. Goulart FR, Valls-Solé J. Patterned electromyographic activity in the sitto-stand movement. Clin Neurophysiol. 1999;110(9):1634-40.

24. Lloyd DG, Besier TF. An EMG-driven musculoskeletal model to estimate muscle forces and knee joint moments in vivo. J Biomech. 2003; 36(6):765-76.

25. Kim MH, Yi CH, Yoo WG et al. EMG and kinematics analysis of the trunk and lower extremity during the sit-to-stand task while wearing shoes with different heel heights in healthy young women. Hum Mov Sci. 2011;30(3):596-605.

26. Landry SC, Nigg BM, Tecante KE. Standing in an unstable shoe increases postural sway and muscle activity of selected smaller extrinsic foot muscles. Gait Posture. 2010;32(2):215-9. 
27. Roy G, Nadeau S, Gravel D. Side difference in the hip and knee joint moments during sit-to-stand and stand-to-sit tasks in individuals with hemiparesis. Clin Biomech (Bristol, Avon). 2007;22(7):795-804.

28. Palluel E, Ceyte H, Olivier I et al. Anticipatory postural adjustments associated with a forward leg raising in children: Effects of age, segmental acceleration and sensory context. Clin Neurophysiol. 2008;119(11): 2546-54.

29. Shindle MK, Ranawat AS, Kelly BT. Diagnosis and management of traumatic and atraumatic hip instability in the athletic patient. Clin Sports Med. 2006;25(2):309-26.

30. Mason JB. Acetabular labral tears in the athlete. Clin Sports Med. 2001;20(4):779-90.

31. McCarthy JC, Noble PC, Schuck MR et al. The Otto E. Aufranc Award: The role of labral lesions to development of early degenerative hip disease. Clin Orthop Relat Res. 2001;(393):25-37.

32. Heller MO, Bergmann G, Deuretzbacher G et al. Musculo-skeletal loading conditions at the hip during walking and stair climbing. J Biomech. 2001;34(7):883-93.

33. Philippon MJ. The role of arthroscopic thermal capsulorrhaphy in the hip. Clinics in Sports Medicine. 2001;20:817-29.
34. Bernardi M, Solomonow M, Baratta RV. Motor unit recruitment strategy of antagonist muscle pair during linearly increasing contraction. Electromyogr Clin Neurophysiol. 1997;37(1):3-12.

35. Ebenbichler GR, Kollmitzer J, Glöckler L et al. The role of the biarticular agonist and cocontracting antagonist pair in isometric muscle fatigue. Muscle Nerve. 1998;21(12):1706-13.

36. Hagood S, Solomonow M, Baratta R et al. The effect of joint velocity on the contribution of the antagonist musculature to knee stiffness and laxity. Am J Sports Med. 1990;18(2):182-7.

37. Jones RK, Chapman GJ, Parkes MJ et al. The effect of different types of insoles or shoe modifications on medial loading of the knee in persons with medial knee osteoarthritis: A randomised trial. J Orthop Res. 2015; 19:doi:10.1002/jor.22947.

38. Buchecker M, Wagner H, Pfusterschmied J et al. Lower extremity joint loading during level walking with Masai bare foot technology shoes in over weight males. Scand J Med Sci Sports. 2012;22(3):372-80.

39. Thelen DG, Schultz AB, Alexander NB et al. Effects of age on rapid ankle torque development. J Gerontol A Biol Sci Med Sci. 1996;51(5):M22632. 